\title{
SALL4 wt Allele
}

National Cancer Institute

\section{Source}

National Cancer Institute. SALL4 wt Allele. NCI Thesaurus. Code C112907.

Human SALL4 wild-type allele is located in the vicinity of $20 q 13.2$ and is approximately 18 $\mathrm{kb}$ in length. This allele, which encodes Sal-like protein 4, is involved in both the positive and negative regulation of transcription. Mutation of the gene is associated with Duaneradial ray syndrome. 